\title{
Use of Pituitary Cells in Primary Culture to Study the Regulation of Gonadotropin Hormone (GtH) Secretion in Rainbow Trout: Setting Up and Validating the System as Assessed by Its Responsiveness to Mammalian and Salmon Gonadotropin Releasing Hormone ${ }^{1}$
}

\author{
C. Weil,${ }^{*}$ P. Hansen, $\dagger$ D. Hyam,$\dagger$ F. Le GaC, ${ }^{*}$ B. Breton, ${ }^{*}$ and L. W. Crim $\neq$ \\ * Laboratoire de Physiologie des Poissons INRA Campus de Beaulieu Avenue du Général Leclerc \\ 35042 Rennes Cedex, France; + Health Sciences Centre, Memorial University of Newfoundland, \\ St John's, Newfoundland Al B 3V6, Canada; and $\$$ Marine Sciences Research Laboratory, \\ Memorial University of Newfoundland, St John's, Newfoundland Al C 5S7, Canada
}

Accepted September 11, 1985

\begin{abstract}
To study the regulation of gonadotropin secretion in rainbow trout in vitro, a method for preparing primary cultures of dispersed pituitary cells is described. Cells were dispersed by collagenase $0.1 \%$ in Hank's saline solution for $20 \mathrm{hr}$ at $12^{\circ}$ and a high yield of viable cells was obtained. Attempts to improve cell functioning were made by varying culture conditions (density of cells initially plated, age of the culture). Cell functioning was assessed by their ability to respond to increasing doses of mammalian and salmon GnRH. Pituitaries were collected from spermiating males whose pituitaries are known to be sensitive to mammalian GnRH in vivo. Using 96-well plates, optimal conditions for good biological activity, are initial plating with $6.2 \times 10^{4}$ cells, incubation with $\mathrm{GnRH}$ for $24 \mathrm{hr}$ on the third day after plating. In these conditions mammalian analog and salmon GnRH induced an increase in $\mathrm{GtH}$ release for doses ranging from $10^{-9}$ to $10^{-6} M$. The $\mathrm{GtH}$ released during the $\mathrm{GnRH}$ incubation period does not decrease the sensitivity of the system since addition of $20 \mathrm{ng}$ of $\mathrm{GtH}$ at the beginning of incubation does not modify the response profile. 1986 Academic Press, Inc.
\end{abstract}

In previous work we have studied the regulation of $\mathrm{GtH}$ secretion by mammalian gonadotropin releasing hormone (mGnRH) in vivo in carp and trout (Weil et al., 1975, 1978). The use of in vitro systems for studying the regulation of gonadotropin hormone (GtH) secretion provides a number of advantages over in vivo experimentation. In such a system the pituitary is isolated from neural influences and the action of test substances can be easily studied.

The use of dispersed pituitary cells is more suitable than the use of whole organs or half organs because it requires less donor animals and provides homogeneous

1 The results were presented in part as a poster at the 7th Conference of the European Society for Comparative Physiology and Biochemistry, Barcelona, Spain. August 26-28, 1985 (Weil, 1985). replicates since the pituitaries are pooled. These dispersed cells can be used in monolayer culture (static model) or anchored to beads and used in a perifusion system (dynamic model). In the former case each well is used for a test substance whereas in the latter, cells are usually used for several tests after a recovery period. For this reason we preferred to use a primary culture in a static model. However, dispersion and culture conditions can affect cell functioning and therefore the optimization of these parameters can greatly increase the usefulness of this technique. In the present work, we decided to study a fcw such parameters. Cell functioning was assessed by the ability of gonadotrophs present in the primary cell culture to respond to mammalian GnRH analog (D-Ala ${ }^{6}$ LHRH) and salmon GnRH (sGnRH) whose structure 
has been recently determined (Sherwood et al., 1983). Trials were conducted on adult spermiating trout which are known to have high pituitary GtH levels and to be responsive to $\mathrm{mGnRH}$ in vivo (Weil et al., 1978).

\section{MATERIALS AND METHODS}

Animals. All the studies were conducted on 2-yearold spermiating males or on thosc just beginning regression of a spring-spawning strain reared at the fish farm of Gournay (Oise).

Cell preparation. Pituitary glands were removed from 10 to 20 fish and placed in ice-cold Hank's balanced salt solution (GIBCO Laboratories), buffered with $20 \mathrm{~m} M$ Hepes (P-L Biochemicals, Inc.) and $9 \mathrm{~m} M$ sodium bicarbonate as indicated by Wolf (1982) and supplemented with penicillin $(100 \mathrm{U} / \mathrm{ml})$, streptomycin $(100 \mu \mathrm{g} / \mathrm{ml})$, and fungizone $(0.25 \mu \mathrm{g} / \mathrm{ml})$ (GIBCO Laboratories). The buffered saline solution had an osmotic pressure of $300 \mathrm{mOsm} / \mathrm{kg}$ and a $\mathrm{pH}$ of 7.5 , characteristic values of rainbow trout blood plasma. Pooled glands were rinsed with the buffered saline solution and chopped into small pieces with a surgical blade. The tissue fragments were transferred for dispcrsion to a siliconized glass-stoppered flask filled with 20-30 $\mathrm{ml}$ of Hank's buffered solution containing $0.1 \%$ (wt/ vol) collagenase (Boehringer Mannheim) and $3 \%$ (wt/ vol) BSA (RIA grade-Sigma). The mixture was incubated at $12^{\circ}$ for $20 \mathrm{hr}$ and during this period dissociation was mechanically aided by aspirating the fragments three times in a siliconized Pasteur pipette. Cells were harvested by centrifugation at $200 \mathrm{~g}$ for 10 $\min$ at $15^{\circ}$ and washed twice with the culture medium. The culture medium consisted of RPMI (GIBCO Laboratories) containing $20 \mathrm{~m} M$ Hepes, $9 \mathrm{~m} M \mathrm{NaHCo}_{3}$ and had a $\mathrm{pH}$ of 7.5 and an osmotic pressure of 300 $\mathrm{mOsm} / \mathrm{kg}$. This culture medium was supplemented with $2 \%$ of a serum substitute, ultroser G or SF (IBF) and with the same dosage of antibiotic-antimycotic as previously described. Cells were resuspended in $1 \mathrm{ml}$ of culture medium. Cell counting and cell viability were determined by mixing $40 \mu \mathrm{l}$ of the cell suspension with $10 \mu$ l of $0.1 \%$ trypan blue (BDH chemicals) in $0.01 M$ phosphate buffer ( $\mathrm{pH}$ 7.3) and examining the cells in a Thoma hemocytometer. After counting, the cells were diluted to $2.5 \times 10^{5}$ cells or $1.25 \times 10^{5}$ cellsiml of medium and $250 \mu \mathrm{l}$ of suspension (i.e., 6.2 $\times 10^{4}$ cells or $3.1 \times 10^{*}$ cells) were plated in each well of 96-well plates (NUNC). The dishes were maintained at $18^{\circ}$.

Microscopical observation of the cells was performed each day after plating. After 2, 3, or 5 days of culture (preincubation), the cells were washed twice with $250 \mu \mathrm{l}$ of ultroser and antibiotic-antimycotic free culture medium and subsequently reincubated in 250 $\mu l$ of this medium with or without increasing concen- trations of synthetic GnRH, A synthetic analog of LHRH, des-Gly ${ }^{10}$ D-Ala ${ }^{6}$ LHRH ethylamide (Beckmann), as well as a synthetic salmon GnRH (Breton et al., 1984) synthesized according to the sequence de. scribed by Sherwood et al. (1983) were used at different doses $\left(10^{-12}\right.$ to $\left.10^{-6} \mathrm{M}\right)$. At the end of the incuhation perind (at $18^{\circ}$ for 6 to $24 \mathrm{hr}$ ) the media were collected, centrifuged, and stored at $-20^{\circ}$ for subse quent determination of $\mathrm{GtH}$. The intracellular concentration of $\mathrm{GtH}$ was determined in some experiments. After the removal of the incubation media, culture dishes were washed twice with buffered saline solu tion and 200 wl of radioimminnoassay buffer containing $0.1 \%$ (vol/vol) of Triton X-100 (Serva) was added to each well for 3 to $4 \mathrm{hr}$ at $18^{\circ}$ until complete breaking up of the cells was achieved as assessed by micro. scopic observation. The cell lysate was stored at $-20^{\circ}$ until GtH measurement. Results were expressed as nanograms of $\mathrm{GtH}$ released or present in the cell extracts per number of cells initially plated for the specified time intervals.

The overload of the medium by GtH was made by adding $20 \mathrm{ng} /$ well of a pure salmon $\mathrm{GtH}$ (Breton et al, 1978).

GtH measurement. A radioimmunoassay ( $R I A_{n}$ ) established for assaying plasma and pituitary $\mathrm{GtH}$ content was used as described by Breton et al. (1971b). This RIA used a pure salmon GtH as a standard against guinea pig anti-trout $\mathrm{GtH}$. Assessment of this RIA for measuring GtH contained in the cells and in the culture medium was performed by comparing the parallelism of the usual standard curve and that of the standard curve containing $0.1 \%$ Triton or culture medium in a logit versus log dose representation.

Statistical analysis. The data were analyzed using an analysis of variance and comparisons between means were made using the Newman-Keuls test.

\section{RESULTS}

\section{Dissociation and Culture Procedures}

The exposure of pituitaries to collagenase at $12^{\circ}$ for $20 \mathrm{hr}$ produced a high yield of single cells but some clusters were also observed. Cell viability tested immediately after dissociation was high and the mean yield of live cells was $88.98 \pm 1.49 \%$ for the three trials reported in the present work.

Microscopically, freshly dispersed cells had spherical shapes. After $24 \mathrm{hr}$ in culture at $18^{\circ}$ they still had this shape and had begun division. By Day 2, the cells had flattened, spread, and begun to be at- 
tached. The entire area of the dish was not covered with cells when initial plating is done with $6.2 \times 10^{4}$ cells. On the other hand by Day 3 cells were firmly attached and the entire area was covered with cells and by Days 4 and 5 the wells had the same appearance.

By Day 3, when wells were initially plated with half the quantity of cells $(3.1 \times$ $10^{4}$ cells) the density of spread cells was equivalent to that observed on Day 2 after an initial plating of $6.2 \times 10^{4}$ cells per dish.

\section{Assessment of the Biological Activity of}

Pituitary Gonadotrophs Present in the

\section{Primary Culture}

Cells $\left(6.2 \times 10^{4}\right)$ were initially plated in control and experimental dishes. The biological activity of the pituitary gonadotrophs was tested by their ability to respond to GnRH stimulation after 3 days of preincubation. At that time cells were firmly attached, had spread and had covered the entire dish area.

(I) Time course of $\mathrm{GtH}$ release by con-

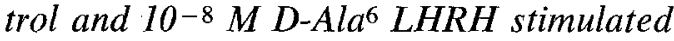
plates (Fig. 1). GtH release was studied 6, 12 , and $24 \mathrm{hr}$ during the incubation period in control and experimental quadruplicates. GtH levels rose slowly in the media collected from control dishes whereas a marked increase was noticed in GnRH stimulated ones. However, GtH levels were highly different from control ones

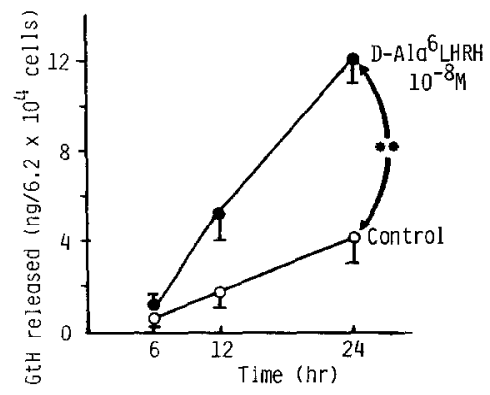

FIG. 1. Time course of GtH release by control and $10^{-8} M$ D-Ala ${ }^{6}$ LFIRII stimulated wells initially plated with $6.2 \times 10^{4}$ cells. Values are $\bar{x} \pm \operatorname{SEM}(n=4) . * * P$ $<0.005$. only at $24 \mathrm{hr}(P<0.005)$. As a consequence a period of $24 \mathrm{hr}$ was used in subsequent incubations.

(2) $\mathrm{GtH}$ release with various concentrations of D-Ala ${ }^{6}$ LHRH or sGnRH by cultured pituitary cells (Fig. 2). Quadruplicates of monolayer cultures were submitted for $24 \mathrm{hr}$ to increasing doses ( 0 to $1^{-6} M$ ) of D-Ala ${ }^{6}$ LHRH and sGnRH, respectively. Doses ranging from $10^{-12}$ to 10-10 $M$ of both types of GnRH did not significantly change $\mathrm{GtH}$ release in comparison with controls (dose 0 ) and mean GtH levels were $7.62 \pm 0.39 \mathrm{ng} / 6.2 \times 10^{4}$ cells. On the other hand, doses ranging from $10^{-9}$ to $10^{-6} M$ induced a significant increase compared with controls and mean $\mathrm{GtH}$ levels were, respectively, $16.34 \pm 0.96 \mathrm{ng} /$ well with $\mathrm{D}-\mathrm{Ala}^{6} \mathrm{LHRH}$ and $16.69 \pm 0.56$ $\mathrm{ng} /$ well with sGnRH.

\section{Influence of the Preincubation Duration and of Cell Density Initially Plated on the Biological Activity of the Gonadotrophs in Primary Cell Culture as Assessed by Their Response to Incubation with GnRH}

During a 24-hr incubation period increasing doses of GnRH (0 to $\left.10^{-6} M\right)$ were

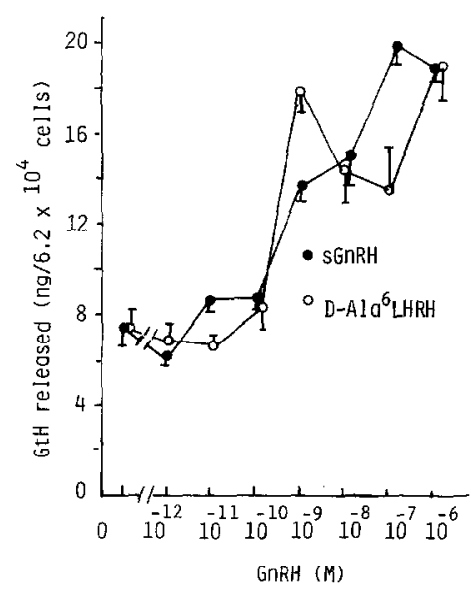

FIG. 2. GtH release with various concentrations of D-Ala ${ }^{6}$ LHRH and sGnRH by $6.2 \times 10^{4}$ cells initially plated, during the $24-\mathrm{hr}$ incubation period. Incubation was performed 3 days after plating. Values are $\bar{x} \pm$ $\operatorname{SEM}(n=4)$. 
tested on preadruplicate wells either 2, 3 , and 5 days after an initial plating with 6.2 $\times 10^{4}$ cells or 3 days after an initial plating with $3.1 \times 10^{4}$ cells. In each experimental condition the biological activity of the gonadotrophs was assessed by studying basal GtH release (GtH present in the dose 0 wells at the end of the incubation period), cell GtH content (measured at the term of the incubation period), and the responsiveness to various doses of sGnRH (GtH present in the GnRH stimulated wells at the end of the incubation period).

(I) Basal GtH release and cell GtII content (Table 1). As the different doses of sGnRH treatment did not influence cell GtH content $(P>0.05)$, this parameter is expressed by the mean of all the wells.

Similar basal GtH levels and cell GtH contents were observed 2 days after an initial plating with $6.2 \times 10^{4}$ cells and 3 days after an initial plating with $3.1 \times 10^{4}$ cells. These values were significantly lower than those noticed in wells initially plated with $6.2 \times 10^{4}$ cells and preincubated for 3 and 5 days. These observations are in agreement with the microscopic observation of cell development in the dishes and related above.

(2) Responsiveness to GnRH (Fig. 3). Following an initial plating with $6.2 \times 10^{4}$ cells, only the highest tested dose of sGnRH $\left(10^{-6} M\right)$ induced a significant $\mathrm{GtH}$ release compared to basal level when incubation is performed after 2 and 5 days of preincubation. On the other hand, a significant $\mathrm{GtH}$ release was observed for doses ranging from $10^{-8}$ to $10^{-6} \mathrm{M}$ when incubation is performed after 3 days of preincubation. As mentioned above, increase in GtH release was gradual and began at a dose of $10^{-9} M$. On Day 3 basal and sGnRH induced GtH release presented good homogeneity among replicates and the global coefficient of variation was $18 \%$. On the other hand, 5 days after plating these two parameters presented heterogeneous values. The global coefficient of variation was $63 \%$ and it is the reason why, a significant increase in $\mathrm{GtH}$ release was noticed only for the highest tested dose $\left(10^{-6} M\right)$.

Following an initial plating with a low

TABLE 1

Influfnce of the Preincubation Duration and of the Cell Density Intrially Plated on Basal Gth Release and Gth Content of Gonadotrophs Present in Primary Cell Culture and Submttted to a 24-hr INCUBATION PERIOD WITH SGnRH

\begin{tabular}{|c|c|c|c|c|}
\hline & \multirow{2}{*}{$\begin{array}{l}\text { Number of cells } \\
\text { initially plated }\end{array}$} & \multicolumn{3}{|c|}{ Days of preincubation } \\
\hline & & 2 & 3 & 5 \\
\hline $\begin{array}{l}\text { Basal GtH } \\
\text { release } \\
a, b\end{array}$ & $\begin{array}{l}6.2 \times 10^{4} \\
3.1 \times 10^{4}\end{array}$ & $\begin{array}{c}0.85 \pm 0.35 * \\
\text { (4) }\end{array}$ & $\begin{array}{c}7.72 \pm 0.64 \\
(4) \\
0.99 \pm 0.29 * \\
\text { (4) }\end{array}$ & $\begin{array}{c}5.35 \pm 1.86 \\
(4)\end{array}$ \\
\hline $\begin{array}{l}\text { Cells GtH } \\
\text { content }^{a, c}\end{array}$ & $\begin{array}{l}6.2 \times 10^{4} \\
3.1 \times 10^{4}\end{array}$ & $\begin{array}{c}84.51 \pm 4.61^{* *} \\
(24)\end{array}$ & $\begin{array}{c}132.94 \pm 4.12 \\
(24) \\
84.52 \pm 4.93^{* *} \\
(24)\end{array}$ & $\begin{array}{c}132.26 \pm 6.66 \\
(24)\end{array}$ \\
\hline
\end{tabular}

$a$ Values are $\bar{x} \pm$ SEM and expressed as nanograms per number of cells initially plated. $(\quad)=$ number of replicates.

${ }_{b}$ Corresponds to the response to the 0 dose of sGnRH (see the results).

$c$ Values are the mean of control and sGnRH treated wells since the different doses of sGnRH did not influence cell GtH content (see the results).

*,** Values significantly different from wells initially plated with $6.2 \times 10^{4}$ cells and studied after 3 and 5 days of preincubation. $* P<0.02, * * P<0.001$. 
density of cells $\left(3.1 \times 10^{4}\right.$ cells $)$ a response to GnRH was observed on Day 3 only for the highest tested dose $\left(10^{-6} M\right)$.

\section{Influence of an Overload of GtH in the}

Media on Gonadotrophs Responsiveness to Varying Doses of $s \mathrm{G} n \mathrm{RH}$

Three days after plating, quadruplicate dishes containing $6.2 \times 10^{4}$ cells initially were submitted for a 24-hr incubation period to $20 \mathrm{ng}$ of $\mathrm{GtH}$ plus increasing doses of sGnRH $\left(0-10^{-6} M\right)$ or to sGnRH alone (same culture as previously reported Table 1-Fig. 3). Basal GtH levels (dose 0) are $27.21 \pm 0.89 \mathrm{ng}$ and $7.72 \pm 0.64 \mathrm{ng} / \mathrm{dish}$, respectively. Figure 4 shows sGnRH induced GtH release expressed as increase over basal levels. An overload of $\mathrm{GtH}$ did not modify sGnRH induced GtH release. GtH patterns are similar in control and experimental dishes: a significant increase in $\mathrm{GtH}$ release was obtained for $\mathrm{sGnRH}$ doses ranging from $10^{-8}$ to $10^{-6} M$ and the values obtained are not significantly different.

\section{DISCUSSION}

The use of different in vitro systems for studying the regulation of $\mathrm{GtH}$ secretion is now commonplace in mammals. In teleost fish some attempts have been made. Authors used either hemipituitaries in shortterm incubation (carp: Breton et al., (1971a, 1972) or whole organs in short term incubation (rainbow trout: Crim and Evans, 1980) and in organ culture (rainbow trout: Făhraeus-van Ree et al., 1983). Recently pituitary fragments in a perifusion system have been described in goldfish (Mackenzie et al., 1984). The use of dispersed pituitary cells of the whole pituitary has been also reported either in short-term incubation (rainbow trout: Fåhraeus-van Ree et al., 1982a,b) or in primary culture in a static model (rainbow trout: Fåhraeusvan Ree et al., 1982b; carp: Ribeiro and Ahne, 1982; Ribeiro et al., 1983) and in a perifusion system (goldfish: Chang et al., 1984). Recently a primary culture of purified pituitary gonadotrophs have been set up for African catfish (Leeuw et al., 1984). The present paper describes a technique of dispersion and culture of pituitary cells in rainbow trout. The enzymatic collagenase procedure that we used produces a high yield of living cells which are firmly attached on Day 3 of culture and are able to be responsive to GnRH. Using another enzymatic dispersion technique, Fåhraeusvan Ree et al, (1982b) have also obtained dispersed pituitary cells of rainbow trout able to be kept in primary culture and to be responsive to GnRH. In our study the response to GnRH is a function of incubation time, as already described for short-term
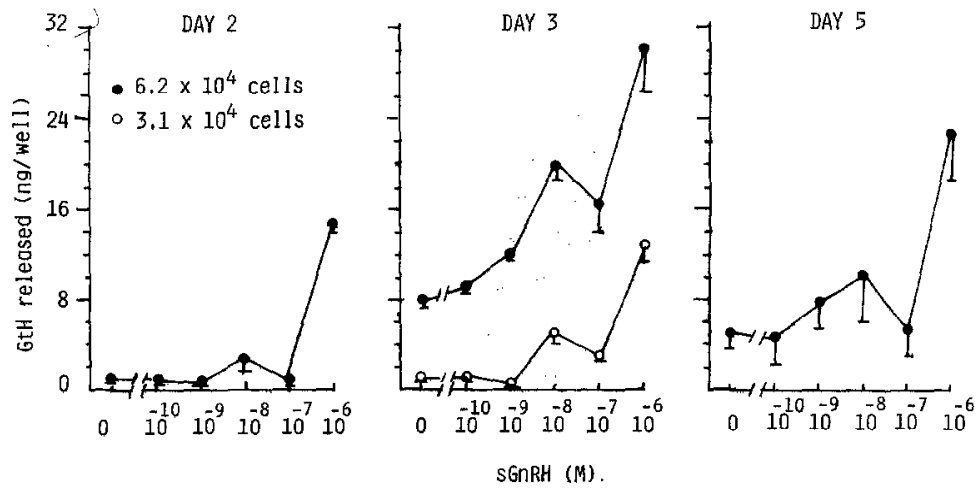

FIG. 3. Influence of the preincubation duration and of the cell density initially plated on the responsiveness of the gonadotrophs to various doses of sGnRH. Wells were initially plated with $6.2 \times 10^{4}$ cells or $3.1 \times 10^{4}$ cells and a $24-\mathrm{hr}$ incubation with sGnRH was performed on Days 2,3 , and 5 after plating. Values are $\bar{x} \pm \operatorname{SEM}(n=4)$. 


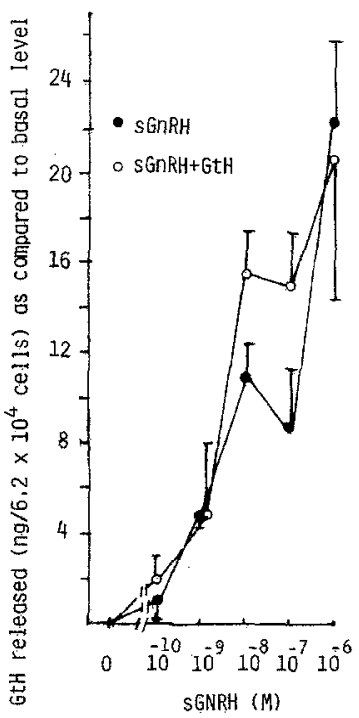

FIG. 4. Influence of an overload of $20 \mathrm{ng}$ of $\mathrm{GtH}$ on cells responsiveness to various doses of $\mathrm{sGnRH}$ during the 24-hr period of an incubation performed 3 days after plating. Wells were initially plated with 6.2 $\times 10^{4}$ cells. The results for sGiRH stimelated GtH release without a $\mathrm{GtH}$ overload come from the same cultures as shown in Fig. 3. Values are $\tilde{x} \pm \operatorname{SEM}(n=$ 4) and are expressed as GiH increase compared to basal level ( $\mathrm{GtH}$ measured in doses 0 wells).

incubation of whole pituitary in trout (Crim and Evans, 1980) or for carp pituitaries in monolayer culture (Ribeiro et al., 1983). We found that a $24-\mathrm{hr}$ incubation period is necessary to observe a $\mathrm{GtH}$ release highly different from control wells. Furthermore, we demonstrated for the first time that GnRH stimulates $\mathrm{GtH}$ release in a dose-related fashion from isolated pituitary cells of rainbow trout. We observed a response to GnRH for doses ranging from $10^{-9}$ to $10^{-6}$ $M$ of both tested peptides, the salmon GnRH and the mammalian LHRH analog (D-Ala ${ }^{6}$ LHRH). The average increase in comparison with basal release (dose 0 ) was approximately two and a half times higher. As the two tested peptides are active in the same dose range we think that they are equipotent in our in vitro system. To our knowledge our work is the second one comparing in vitro the action of mammalian and salmon GnRH on GtH secretion. The first trials were made in goldfish with superfused pituitary fragments collected from postspawning males by Mackenzie et al. (1984). Because both peptides were active in the same dose range, elicited response profiles which were similar in time course and stimulated maximal responses of equal magnitude, these authors concluded also that the peptides are approximately equipotent in their system. However, in vivo in goldfish, Peter et al. (1985) have recently demonstrated that D-Ala ${ }^{6}$ LHRH is more active than sGnRH in terms of magnitude and duration of the $\mathrm{GtH}$ response. These authors suggest that in vivo the decreased degradation of LHRHa may be the primary factor determining its potency. As, in our static in vitro system, we did not study the degradation of both peptides as well as their pituitary receptor binding affinity during the 24-hr incubation period, we cannot determine the factors contributing to their equal efficiency.

As the gonadotrophs present in our primary cultures were sensitive to GnRH, we attempted to optimize the conditions of culture to increase the sensitivity of our system and to decrease the numbers of fish required. First the time was varied between plating and incubation with GnRH. Second, wells were initially plated with half the quantity of cells. It appears that the responsiveness of our system is dependent on the number of cells present in the dish at the time of GnRH incubation. In fact, when the density of cells was weak after either a low initial plating $\left(3.1 \times 10^{4}\right.$ cells $)$ or when cells are not fully grown and firmly attached on Day 2 after an initial plating with $6.2 \times 10^{4}$ cells; only the highest dose of sGnRH $\left(10^{-6} \mathrm{M}\right)$ induced, at the term of the 24-hr period of incubation, an increase in $\mathrm{GtH}$ release. In both cases, the small number of cells was assessed by microscopic observation and corroborated by the low cells GtH content and basal Gth re lease in comparison with those observed in wells initially plated with $6.2 \times 10^{4}$ cells 
and stimulated on Day 3. A longer duration of incubation could have been sufficient to increase the sensitivity of this in vitro system and to allow us to use a smaller amount of cells. However, by increasing the duration of incubation, we may have encountered some problems related to the age of the culture. Indeed, we noticed heterogeneous $\mathrm{GtH}$ release in control wells (dose 0 ) as well as in sGnRH treated wells when incubation with $\mathrm{GnRH}$ is performed 5 days after plating. As a consequence, this heterogeneity caused a decrease in the sensitivity of our system since only the highest dose of GnRH, i.e., $10^{-6} M$, induced a significant increase in $\mathrm{GtH}$ release. However, by microscopic observation no changes in cell morphology were observed and the plates were not invaded by fibroblast proliferation as already described in mammals ( $O^{\prime}$ Conner et al., 1980). In mammals, it is well known that in monolayer culture, basal as well as LHRH stimulated LH and FSH release decrease with culture time (Vale et al., 1972; Tixier-Vidal et al., 1973). However, this decrease appears more than 1 week after plating. In our work, on Day 5 basal $\mathrm{GtH}$ release during the incubation period, although lower, is not significantly different from the one seen on Day 3. The fact that spontaneous $\mathrm{GtH}$ release as well as sGnRH induced GtH release are heterogeneous between replicates, leads us to think that this heterogeneity is not due to the damage of GnRH receptor. This heterogeneity could be due to a decrease in the synthesis capacity of the cells with time. Additional studies on the kinetics of the synthesis capacity of gonadotrophs present in the primary culture are necessary to confirm or refute this hypothesis.

Therefore, optimal conditions for studying the regulation of $\mathrm{GtH}$ secretion by GnRH in mature male rainbow trout in 96well plates are initial plating with $6.2 \times 10^{4}$ cells, incubation with GnRH 3 days after plating and a duration of incubation of 24 hr. However, the presence of released $\mathrm{GtH}$ in the medium for 24 hr could have interfered with the sensitivity of the system. As the pattern of $\mathrm{sGnRH}$ induced $\mathrm{GtH}$ release as well as the sensitivity of the system were not modified when we added GtH in the wells, we conclude that this static in vitro system is convenient for a certain type of studies on regulation of GtH synthesis. Preliminary work in progress, unreported here and conducted on males and females at different stages of the sexual cycle corroborate this fact since the gonadotrophs respond to $\mathrm{GnRH}$ in a characteristic pattern as predicted from in vivo experiments (Weil et al., 1978). Further investigations are in progress to clarify this variable pituitary responsiveness to GnRH throughout the sexual cycle and to study the possible role of different steroids on its variation.

\section{ACKNOWLEDGMENTS}

The authors extend their thanks to Ms. Solari for her helpful advice and assistance for statistical analysis. Thanks are also due to Mrs. Marcuzzi for her technical assistance in a part of the study and to Mrs. Lemoniz and M. Provost for typing the manuscript. The visit of C.W. to St. John's was made possible by CNRS (France) and supported by a Grant 1178/GG/81 from INRA (France).

\section{REFERENCES}

Anonymous (1970). The role of LH-RH in induction of spawning in grass carp (Ctenopharyngodon idellus). II. Ultrastructural study of pituitary gonadotrophs. Sci. Sin. 21, 390-396.

Breton, B., Jalabert, B., Billard, R., and Weil, C. (1971a). Stimulation in vitro de la libération d'hormone gonadotrope hypophysaire par un facteur hypothalamique chez la Carpe (Cyprinus carpio). C.R. Acad. Sci. Paris, Ser. D. 273, 2591-2594.

Breton, B., Kann, G., Burzawa-Gérard, E., and Billard, R. (1971b). Dosage radio-immunologique d'une hormone gonadotrope de Carpe Cyprinus carpio L.). C.R. Acad. Sci. Paris, Ser. D. 272, 1515-1517.

Breton, B., Weil, C., Jalabert, B., and Billard, R. (1972). Activité réciproque des facteurs hypothalamiques de Bélier (Ovis aries) et de poissons téléostéens sur la sécrétion in vitro des hormones gonadotropes $\mathrm{c}-\mathrm{HG}$ et $\mathrm{LH}$ respectivement par des hypophyses de Carpe et de Bélier. C.R. Acad. Sci. Paris, Ser. D. 274, 2530-2533. 
3reton, B., Motin, A., Kah, O., Lemenn, F., Geoffre, S., Precigoux, G., and Chambolle, P. (1984). Dosage radio-immunologique homologue d'un facteur hypothalamique de stimulation de la fonction gonadotrope hypophysaire de Saumon s-Gn-RH. C.R. Acad. Sci. Paris 299 (Sér. III), 383-388.

Chang, J. P., Mackenzie, D. S., Gould, D. R., and Peter, R. E. (1984). Effects of dopamine and norepinephrine on in vitro spontaneous and gonadotropin-rcleasing hormonc-induced gonadotropin release by dispersed cells or fragments of the goldfish pituitary. Life Sci. 35, 2027-2033.

Crim, L. W. and Evans, D. M. (1980). LH-RH-stimulated gonadotropin release from the rainbow trout pituitary gland: An in vitro assay for detection of telenst gonadotropin releasing factor(s). Gen. Comp. Endocrinol 40, 283-290.

Fåhraeus-van Ree, G. E., Guldenaar, S. E. F., and Gielen, J. T. (1982a). Fine structure and function of isolated gonadotropic cells as revealed from pituitaries of immature rainbow trout (Salmo gairdneri), by means of a new enzymatic dispersion technique. Cell Tissue Res. 226, 641-653.

Făhraeus-van Ree, G. E., Panis, C. J., Kleijne, J. A. F. W., Gielen, J. T. h., and Van Oordt, P. G. W. J. (1982b). Gonadotropic hormone production in enzymatically dispersed pituitary cells of the trout, Salmo gairdneri. In Goos HJTh, Richter. CJJ (eds) "'Proc. Int. Symp. Repr. Phys. Fish" (H. J. Th. Goos and C. J. J. Richter, eds.), p. 53. Pudoc, Wageningen.

Fåhraeus-van Ree, G. E., Van Vlaardingen, and Gielen, J. T. (1983). Effect of $17 \alpha$-methyltestosterone, estradiol-17\% and synthetic LHRH on production of gonadotropic hormone in pituitaries of rainbow trout (organ culture). Cell Tissue Res. $232,157-176$

de Leeuw, R., Goos, H. J. Th., Peute, J., Van Pelt, A. M. M., Burzawa-Gérard, E., and Van Oordt, P. G. W. J. (1984). Isolation of gonadotrops from the pituitary of the African catfish, (Clarias inzera). Morphological and physiological characterization of the purified cells. Cell Tissue Res. 236, 669-675.

Mackenzie, D. S., Gould, D. R., Peter, R. E., Rivier, J., and Vale, W. W. (1984). Response of superfused goldfish pituitary fragments to mammalian and salmon gonadotropin-releasing hormones. Life Sci. 35, 2019-2026.

O'Conner, J. L., Allen; M. B., and Malesh, V.: B. (1980). Castration effects of the response of rat pituitary cells to luteinizing hormone-releasing hormone: Retention in dispersed cell culture. Endocrinology, 106, 1706-1714.

Peter, R. E., Nahorniak, C. S., Sokolowska, M., Chang, J. P., Rivier, J. E., Vale, W. W., King, J. A., and Millar, R. P. (1985). Structure activity relationships of mammalian, chicken, and salmon gonadotropin releasing hormones in vivo in goldfish. Gen. Comp. Endocrinol. 58, 231-242.

Ribeiro, L., and Ahne, W. (1982). Fish cell culture: Initiation of a line of pituitary cells from carp (Cyprinus carpio) to study the release of gonadotropin in vitro. In Vitro $18,419-420$

Ribeiro, L., Ahne, W., and Lichtenberg. V. (1983). Primary culture of normal pituitary cells of carp (Cyprinus carpio) for the study of gonadotropin release. In Vitro $19,41-45$.

Sherwood, N., Eiden, L., Brownstein; M., Spiess, J., Rivier, J., and Vale, W. (1983). Characterization of a teleost gonadotropin-releasing hormone. Proc. Natl. Acad. Sci. USA 80, 2794-2798.

Tixier-Vidal, A., Kerdelhuè, B., and Jutisz, M. (1973). Kinetics of release of luteinizing hormone ( $L H$ ) and follicle stimulating hormone (FSH) by primary cultures of dispersed: rat anterior pituitary cells. Chronic effect of synthetic LH and FSH releasing hormone. Life Sci. 12, 499-509.

Vale, W., Grant, G., Amoss, M., Blackwell, R., and Guillemin, R. (1972). Culture of enzymatically dispersed anterior pituitary cells: functional validation of a method. Endocrinology 91, 562-572.

Weil, C., Breton, B., and Reinaud, P. (1975). Etude de la résponse hypophysaire à l'administration de Gn-RH exogène au cours du cycle reproducteur annuel chez la Carpe (Cyprimus carpio L.). C.R. Acad. Sci. Paris, Ser. D. 280, 2469-2472.

Weil, C., Billard, R., Breton, B., and Jalabert, B. (1978). Pituitary response to LH-RH at diflerent stages of gametogenesis in the rainbow troat (Salmo gairdneri). Ann. Biol. Anin. Biochem. Biophys. 18, 863-869.

Wolf, K., and Ahne, W. (1982). Fish cell culture. Adv. Cell Cult. 2, 305-327. 